\title{
Modul Berbasis Inkuiri Terbimbing Berdasarkan Hasil Penelitian pada Materi Sistem Reproduksi
}

\author{
Nosi Qadariah $^{1}$, Sri Rahayu Lestari ${ }^{1}$, Fatchur Rohman ${ }^{1}$ \\ ${ }^{1}$ Pendidikan Biologi-Universitas Negeri Malang
}

\begin{tabular}{l} 
INFO ARTIKEL \\
\hline Riwayat Artikel: \\
Diterima: 03-05-2019 \\
Disetujui: 26-05-2019
\end{tabular}

Kata kunci:

guided inquiry; research result; reproduction system; inkuiri terbimbing; hasil penelitian;

sistem reproduksi

Alamat Korespondensi:
Nosi Qadariah
Pendidikan Biologi
Universitas Negeri Malang
Jalan Semarang 5 Malang
E-mail: nosiqadariah1201355@gmail.com

\begin{abstract}
ABSTRAK
Abstrack: One of the causes of student's low understanding of reproductive system material is that there are no learning resources available. This research was aimed to produce guided inquiry based module based on the results of research that is valid and practical. ADDIE (Analyze, design, develop, implement, and evaluate) developing model is used in this research. Qualitative and quantitative data are used in the study. The resulting module is very valid and very practical with the validation value by material $92,43 \%$, media $92,43 \%$, field practitioners $95,7 \%$, and practicality $91,3 \%$.

Abstrak: Salah satu penyebab rendahnya pemahaman mahasiswa tentang materi sistem reproduksi yaitu tidak tersedia sumber belajar. Penelitian ini bertujuan untuk menghasilkan modul berbasis inkuiri terbimbing berdasarkan hasil penelitian pada materi sistem reproduksi yang valid dan praktis. ADDIE (analyze, design, develop, implement, and evaluate) adalah model pengembangan yang digunakan pada penelitian. Data kualitatif dan kuantitatif digunakan pada penelitian. Modul dikategorikan sangat valid dan sangat praktis dengan nilai validasi materi $94,84 \%$, media $92,43 \%$, praktisi lapangan $95,7 \%$, dan kepraktisan 91,3\%.
\end{abstract}

Kerangka Kualifikasi Nasional Indonesia (KKNI) merupakan acuan pelaksanaan pembelajaran di Indonesia. Salah satu universitas mengacu pada penerapan KKNI yaitu IKIP Budi Utomo Malang. Adapun poin-poin penting yang tergolong dalam KKNI level 6, yakni dapat mengaplikasi, mengkaji, dan pemanfaatan IPTEKS dalam menyelesaikan masalah merupakan kualifikasi diarahakan harus dimiliki oleh mahasiswa program sarjana IKIP Budi Utomo Malang (Kerangka Kualifikasi Nasional Indonesia, 2015). Perumusan capaian pembelajaran semua matakuliah merupakan upaya mencapai kualifikasi level 6 KKNI. Matakuliah yang terindikasi sulit oleh mahasiswa yaitu fisiologi hewan. Pembelajaran fisiologi hewan dilaksanakan melalui kombinasi diskusi kelompok kecil, demontrasi kelas, tugas mandiri, latihan, dan praktikum (Rencana Pembelajaran Semester Fisiologi Hewan IKIP Budi Utomo Malang, 2018). Namun, pelaksaanaan dalam proses pembelajaran belum sepenuhnya menerapkan metode pembelajaran terdapat di dalam RPS fisiologi hewan. Hasil angket analisis kebutuhan bulan Mei 2018 pada dosen dan 87,9\% mahasiswa menunjukkan pembelajaran secara dominan dilakukan dengan presentasi dan diskusi. Pembelajaran dengan metode ini belum mampu membuat mahasiswa dapat menguasai konsep yang dipelajari. Observasi dilakukan pada materi dalam pembelajaran fisiologi hewan.

Materi sistem reproduksi dianggap sulit oleh dosen dan mahasiswa. Secara dominan materi sistem reproduksi pada matakuliah fisiologi hewan berupa sistem reproduksi manusia. Alasan kesulitan pada materi sistem reproduksi manusia yaitu bersifat abstrak dan kompleks (25\% mahasiswa), konsep bersifat pemahaman (20,8\% mahasiswa), sulit dilakukan aplikasi pada kehidupan nyata (12,5\% mahasiswa), dan kurang ketersediaan sumber belajar (37,5\%). Pembelajaran materi sistem reproduksi manusia menuntut mahasiswa mampu memahami organ reproduksi, menjelaskan mekanisme fisiologi reproduksi, proses fertilisasi, kehamilan, dan persalinan. Pembelajaran aktif dan kreatif melibatkan mahasiswa selama proses pembelajaran adalah solusi untuk dapat mengatasi kesulitan pada materi sistem reproduksi. Pembelajaran yang sesuai yaitu model pembelajaran inkuiri terbimbing dilengkapi hasil penelitian.

Pembelajaran menekankan pada proses berpikir secara kreatif (Llewellyn, 2013) dan analitis (Andika, Suadnyana, \& Zulaikha, 2014; Llewellyn, 2013) untuk mencari (Windschitl, 2018) dan mendapatkan sendiri jawaban (Learning Emergence, 2012) dari permasalahan melalui metode dan sikap ilmiah (Heri, 2014; Peffer, Beckler, Schunn, Renken, \& Revak, 2015) merupakan definisi dari sebuah pembalajaran dengan menerapkan model inkuiri terbimbing. Hasil penelitian akan melengkapi model pembelajaran inkuiri terbimbing. Kelebihan hasil penelitian yang digunakan dalam pembelajaran yaitu sebagai penghubung antara penelitian eksperimental dengan praktik pendidikan di Universitas (Oktavia, Sumitro, \& Lestari, 2015), 
pengalaman belajar bagi mahasiswa (Parmin \& Peniati, 2012), contoh bersifat kontekstual (Fitro, 2014), dan pemahaman secara konkret (Fitriani, 2017). Penelitian yang digunakan yaitu potensi ekstrak bawang tunggal (Allium sativum) terhadap kualitas sperma mencit jantan. Pendekatan pembelajaran model inkuiri dilengkapi hasil penelitian membutuhkan bahan ajar.

Bahan ajar adalah jenis sumber belajar untuk dapat membantu meningkatkan pemahaman mahasiswa dalam memahami materi pembelajaran (Dikmenjur, 2010; Karnes \& Bean, 2009; Yaomi, 2013) termasuk sistem reproduksi. Buku, modul, lembar kerja mahasiswa, handout, dan sebagainya merupakan jenis bahan ajar untuk digunakan selama proses pembelajaran (Daryanto, 2013; Lestari, 2013). Dosen dan 97\% mahasiswa memilih modul sebagai bahan ajar yang dibutuhkan dalam pembelajaran pada materi sistem reproduksi. Pembelajaran akan lebih efektif melalui penggunaan modul (Daryanto, 2013). Modul juga merupakan bahan ajar yang dapat meningkatkan pemahaman mahasiswa (Aisyah \& Purwoko, 2011; Permadi, 2016; Pratama, Widiyatmoko, \& Wusqo, 2016; Rizqiana, Widodo, \& Supardi, 2017; Sari \& Isnur, 2015; Yuanda \& Ristiono, 2017; Zulfadli, 2017). Oleh karena itu, dilakukan penelitian pengembangan modul berbasis inkuiri terbimbing berdasarkan hasil penelitian pada materi sistem reproduksi untuk matakuliah fisiologi hewan.

\section{METODE}

Model pengembangan ADDIE melalui tahapan analisis (analyze), desain (design), pengembangan (develop), implementasi (implement), dan evaluasi (evaluate) (Branch, 2009) adalah model pengembangan yang digunakan untuk mengembangkan modul berbasis inkuiri terbimbing berdasarkan hasil penelitian pada materi sistem reproduksi. Penelitian ini hanya dibatasi pada tahap analisis, desain, pengembangan, dan evaluasi. Jabaran dari setiap tahapan model pengembangan ADDIE sebagai berikut.

\section{Prosedur Penelitian}

Pengetahuan mengenai permasalahan dan kebutuhan pembelajaran adalah fungsi tahap analisis. Observasi kegiatan pembelajaran, wawancara, serta pemberian angket analisis kebutuhan merupakan pelaksanaan tahap analisis. Pada tahap analisis juga ditetapkan tujuan pengembangan yaitu menghasilkan, menguji validitas, dan kepraktisan modul. Sasaran pengembangan modul yaitu mahasiswa offering A Jurusan Biologi IKIP Budi Utomo Malang. Penelitian pengembangan modul dilakukan dari bulan Mei 2018 hingga Desember 2018. Perancangan modul berbasis inkuiri terbimbing berdasarkan hasil penelitian adalah fungsi tahap desain. Penyusunan daftar tugas yang akan dirancang di dalam modul, penampilan objek modul, pembuatan angket validasi, dan angket kepraktisan dilakukan pada tahap desain.

Pengembangan hasil rancangan modul yang telah dibuat pada tahap desain adalah fungsi tahap pengembangan. Tahapan pengembangan meliputi perancangan konten pada dalam modul, termasuk hasil penelitian. Pada tahapan pengembangan juga digunakan media pendukung dalam pembuatan modul dan membuat petunjuk penggunaan modul. Modul yang telah dikembangkan dilakukan uji validitas oleh ahli materi, media, dan praktisi lapangan. Validator modul yaitu Dr. Abdul Gofur, M.Si, Dr. Munzil, S,Pd., M.Si., Dwi Candra Setiawan, S.Si., S.Pd., M.Pd., dan Nila Kartika Sari, S.Si., M.Si. Latar belakang pendidikan dan bidang keahlian merupakan dasar pemilihan validator modul berbasis inkuiri terbimbing berdasarkan hasil penelitian. Uji kepraktisan pada 15 orang mahasiswa Offering A jurusan Biologi IKIP Budi Utomo Malang yang sedang menempuh matakuliah fisiologi hewan setalah modul dinyatakan valid. Pengetahuan tentang kekurangan modul merupakan fungsi tahapan evaluasi sebagai dasar perbaikan modul. Tahap evaluasi dilakukan setiap tahapan pengembangan ADDIE sebelumnya (analisis, desain, dan pengembangan).

\section{Data Penelitian}

Data kualitatif dan kuantitatif merupakan jenis data pada penelitian pengembanagn modul berbasis inkuiri terbimbing berdasarkan hasil penelitian. Pendapat, komentar, dan saran perbaikan dari validator dan mahasiswa adalah sumber data kualitatif. Skor angket penilaian validator, dan kepraktisan oleh mahasiswa adalah sumber data kuantitatif. Instrumen pengumpulan data penelitian berupa angket analisis kebutuhan, angket validasi ahli, dan angket uji coba pendahuluan atau kepraktisan.

\section{Analisis Data}

Deskriptif kualitatif dan kuantitatif merupakan teknik analisis data penelitian pengembangan modul berbasis inkuiri terbimbing berdasarkan hasil penelitian. Pengelompokan informasi berupa pendapat, saran, dan komentar perbaikan dari validator dan mahasiswa sebagai subjek uji kepraktisan merupakan teknis untuk menganalisis data kualitatif. Analisis data kuantitatif untuk angket validasi dan uji kepraktisan menggunakan rumus sebagai berikut.

$$
P(\text { Presentase })=\frac{\sum X(\text { Total jumlah skor jawaban responden })}{\sum X i(\text { Total jumlah skor keseluruhan })} \times 100 \%
$$


Kategori analisis hasil validasi dari validator yaitu sangat valid $(85,01-100,00 \%)$ modul dapat digunakan, cukup valid $(70,01-85,00 \%)$ modul direvisi sedikit sebelum digunakan, kurang valid $(50,01-70,00 \%)$ modul direvisi banyak dan belum dapat digunakan, tidak valid $(01,00-50,00 \%)$ modul tidak boleh digunakan. Kategori analisis hasil kepraktisan dari mahasiswa yaitu sangat praktis $(81,00-100,00 \%)$ modul dapat digunakan, praktis $(61,00-80,00 \%)$ modul direvisi kecil sebelum digunakan, kurang praktis $(41,00-60,00 \%)$ modul direvisi banyak dan belum dapat digunakan, tidak praktis $(21,00-40,00 \%)$ modul tidak boleh digunakan, sangat tidak praktis $(00,00-20,00 \%)$ modul tidak boleh digunakan (Akbar, 2013).

\section{HASIL}

Modul yang dapat digunakan secara mandiri atau melalui bimbingan dosen oleh mahasiswa menjadi produk penelitian. Modul memuat materi sistem reproduksi dan dirancang berbasis inkuiri terbimbing berdasarkan hasil penelitian. Hasil dari setiap tahapan ADDIE dijabarkan sebagai berikut.

\section{Tahap Analisis (Analyze)}

Angket analisis kebutuhan materi sistem reproduksi untuk dosen menunjukkan pembelajaran dilakukan melalui metode presentasi dan diskusi, sumber belajar berupa artikel ilmiah serta sudah efektif untuk meningkatkan pemahaman konsep mahasiswa. Hasil angket analisis kebutuhan untuk dosen juga mennunjukkan proses pembelajaran belum pernah menggunakan modul berbasis inkuiri berdasarkan hasil penelitian. Selain pemberian angket, pada tahap analisis dilakukan wawancara pada dosen. Wawancara menunjukkan bahwa sumber belajar berupa modul dan artikel ilmiah sebagai sumber belajar belum tersedia pada semua materi, contohnya pada sistem reproduksi. Oleh karena itu, dibutuhkan sumber belajar pada materi sistem reproduksi. Dosen pengampu matakuliah sangat setuju apabila dikembangkan modul berbasis inkuiri terbimbing berdasarkan hasil penelitian karena hal ini sangat bagus sekali sebagai inovasi dalam pendidikan untuk mempermudah pendidik selama proses pembelajaran. Hasil penelitian juga dapat dijadikan bagian penting dalam memahami sistem reproduksi dan bermanfaat untuk memberikan informasi terbaru bagi mahasiswa.

Pembelajaran dilakukan secara presentasi dan diskusi (87,9\% mahasiswa) merupakan hasil angket analisis kebutuhan pada mahasiswa. Namun, penggunaan model pembelajaran tertentu untuk peningkatan minat dan motivasi belajar adalah saran yang diberikan mahasiswa. Sebanyak 60,6\% mahasiswa mengalami kesulitan dalam memahami sistem reproduksi dengan alasan materi yang bersifat abstrak dan kompleks (25\% mahasiswa), konsep bersifat pemahaman (20,8\% mahasiswa), sulit dilakukan aplikasi dalam kehidupan nyata (12,5\% mahasiswa), dan kurang ketersediaan bahan ajar yang relevan (37,5\% mahasiswa). Pencarian sumber belajar lain, bertanya pada dosen, dan berdiskusi dengan teman dalam satu kelas menjadi solusi mengatasi kesulitan materi sistem reproduksi. Secara umum, pembelajaran fisiologi hewan sudah menggunakan sumber belajar yang bervariasi, namun hanya terbatas pada materi tertentu saja. Selama proses pembelajaran $69,7 \%$ mahasiswa belum pernah menggunakan modul berbasis inkuiri terbimbing dan $97 \%$ mahasiswa setuju agar dikembangkan modul berbasis inkuiri terbimbing.

Produk modul berbasis inkuiri terbimbing berdasarkan hasil penelitian pada materi sistem reproduksi untuk matakuliah fisiologi hewan, diuji validitas dan kepraktisan adalah tujuan penelitian. Offering A Jurusan Biologi IKIP Budi Utomo Malang akan menggunakan produk selama pembelajaran fisiologi hewan. Penggunaan modul dalam bentuk cetakan ukuran B5. Cara memandu mahasiswa dalam pembelajaran sistem reproduksi di dalam modul melalui model inkuiri terbimbing.

\section{Tahap Desain (Design)}

Perancangan prototype modul berbasis inkuiri terbimbing berdasarkan hasil penelitian merupakan tahapan yang dilakukan pada tahap desain. Rancangan keseluruhan modul berbasis inkuiri terbimbing berdasarkan hasil penelitian dihasilkan pada tahap desain, termasuk menyusun objek di dalam modul. Tiga kegiatan belajar disertai tahap model inkuiri terbimbing merupakan isi modul. Fenomena pada tahap pertama inkuiri didapatkan dari hasil penelitian. Angket validasi dan angket kepraktisan dihasilkan pada tahap desain akan digunakan tahap berikutnya.

\section{Tahap Pengembangan (Develop)}

Pembuatan materi dan fenomena dalam tahap model pembelajaran inkuiri terbimbing dilakukan di tahap awal develop. Fenomna disajikan berdasarkan hasil penelitian pada setiap kegiatan belajar. Pembuatan foto pendukung materi, petunjuk penggunaan modul, angket validasi, dan uji kepraktisan modul dihasilkan pada tahap ini. Validasi ahli materi modul berbasis inkuiri terbimbing berdasarkan hasil penelitian terdiri dari tiga komponen besar, yaitu aspek kelayakan isi, kelayakan penyajian isi, dan kelayakan bahasa. Nilai validitas aspek kelayakan isi yang meliputi 12 butir penilaian sebesar 95\% dengan kategori sangat valid. Nilai validitas aspek kelayakan penyajian isi yang meliputi sepuluh butir penilaian sebesar validitas $98 \%$ dengan kategori sangat valid. Nilai validitas aspek kelayakan bahasa yang meliputi sembilan butir penilaian sebesar $91,1 \%$ dengan kategori sangat valid. Hasil validasi keseluruhan dari validator ahli materi yaitu 94,84\% dengan kategori sangat valid. Validitas ahli media terdiri dari empat komponen besar yaitu aspek kegrafisan, aspek penyajian, aspek kebahasaan, dan aspek modul. Nilai validitas aspek kegrafisan yang meliputi sepuluh butir penilaian sebesar $88 \%$ dengan kategori sangat valid. Nilai validitas aspek penyajian yang meliputi tujuh butir penilaian sebesar 94,28\% dengan kategori sangat valid. Nilai validitas aspek 
kebahasaan yang meliputi enam butir penilaian sebesar 93,33\% dengan kategori sangat valid. Nilai validitas aspek modul yang meliputi 14 butir penilaian sebesar 94,28\% dengan kategori sangat valid. Hasil validasi keseluruhan dari validator ahli media yaitu $92,43 \%$ dengan kategori sangat valid.

Validator ahli praktisi lapangan terdiri dari dua orang untuk melakukan validasi. Validasi ahli praktisi lapangan terdiri dari empat komponen utama yaitu kelayakan bahasa, kelayakan isi, penyajian, dan inkuiri terbimbing. Nilai validasi dari komponen kelayakan bahasa yang meliputi tujuh butir penilaian sebesar 91,4\% dengan kategori sangat valid. Nilai validasi dari komponen kelayakan isi yang meliputi lima butir penilaian sebesar 96\% dengan kategori sangat valid. Nilai validasi dari komponen kelayakan penyajian yang meliputi sepuluh butir penilaian sebesar $97 \%$ dengan kategori sangat valid. Nilai validasi dari komponen kelayakan inkuiri terbimbing yang meliputi delapan butir penilaian sebesar 97,\% dengan kategori sangat valid. Hasil validasi keseluruhan dari validator ahli praktisi lapangan yaitu 95,7\% dengan kategori sangat valid. Uji coba pendahuluan dilakukan pada 15 orang mahasiswa yang sedang menempuh matakuliah fisiologi hewan dan manusia offering A untuk mengetahui nilai kepraktisan modul. Hasil kepraktisan dari 17 butir penilaian yaitu 91,3 dengan kategori sangat praktis.

\section{Tahap Evaluasi (evaluate)}

Hasil evaluasi yang dilakukan pada setiap tahapan pengembangan dijabarkan pada bagian tiga tahapan (analisis, desain, dan pengembangan) sebelumnya.

\section{PEMBAHASAN}

Tiga kegiatan belajar terdapat dalam modul yaitu kegiatan belajar pertama tentang organ reproduksi, kegaiatan belajar kedua tentang fisiologi reproduksi, dan kegiatan belajar ketiga tentang fertilisasi, kehamilan, dan persalinan. Setiap kegiatan belajar dilengkapi dengan tahapan inkuiri terbimbing (Llewellyn, 2013). Fenomena pada setiap kegiatan belajar merupakan hasil penelitian yang telah dilakukan. Hasil penelitian memberikan pengalaman nyata bagi mahasiswa (Parmin \& Peniati, 2012), pemahaman konsep secara konkret (Oktavia, et al., 2015), pengetahuan akan perkembangan dan penemuan terkait materi sistem reproduksi pada modul (Widayati, et al., 2010), selama pembelajaran sebagai bahan ajar (Amin, 2010; Faot, Zubaidah, \& Kuswantoro, 2016), peningkatan kualitas pembelajaran (Yahya, 2010), mempunyai daya adaptasi terhadap ilmu pengetahuan dan teknologi (Mahfudhillah, Al-Muhdhar, \& Sueb, 2017).

Bagian inti modul berbasis inkuiri terbimbing berdasarkan hasil penelitian memuat kegiatan belajar (Sudjana \& Rivai, 2009). Setiap kegiatan belajar terdiri dari materi pembelajaran sesuai capaian pembelajaran pada materi sistem reproduksi. Bagian akhir dari setiap kegiatan pembelajaran terdapat tes formatif. Tes formatif dilengkapi dengan kunci jawaban agar mahasiswa mampu mengukur pemahaman secara mandiri (Asyhar, 2011; Daryanto, 2013; Sudjana \& Rivai, 2009). Soal esai merupakan bentuk soal yang didesain pada tes formatif. Memiliki nilai fungsi informasi lebih baik (Susongko, 2010), memberikan kebebasan pada peserta didik untuk mengekspresikan pemahaman, efektif untuk mengukur tingkat pencapaian kompetensi pada aspek kognitif (Hidayat, Festiyed, \& Fauzi, 2012) adalah alasan penggunaan soal esai pada modul berbasis inkuiri terbimbing berdasarkan hasil penelitian. Pada bagian akhir modul terdapat soal tes sumatif. Soal sumatif berfungsi mengukur secara keseluruhan pemahaman mahasiswa (Arifin, 2009; Darini, Martha, \& Artawan, 2013) mengenai materi sistem reproduksi. Bagian penutup terdiri dari bagian glosarium untuk membantu mahasiswa mengetahui definisi istilah di dalam modul (Susanti, 2016), daftar rujukan, dan biografi penulis.

Validasi modul berbasis inkuiri terbimbing berdasarkan hasil penelitian dilaksanakan oleh ahli materi, media, dan praktisi lapangan. Validasi bertujuan dapat memiliki pengetahuan mengenai kelemahan modul dan digunakan sebagai dasar melakukan perbaikan terhadap modul (Asyhar, 2011). Modul sudah sangat valid dan sangat praktis dari hasil validasi oleh keempat validator. Proses belajar matakuliah fisiologi hewan dapat menggunakan modul berbasis inkuiri terbimbing berdasarkan hasil penelitian. Kelebihan modul yaitu memberi bantuan dosen dan mahasiswa selama proses pembelajaran, penggunaan bahasa dalam modul sesuai dengan tingkat berpikir mahasiswa, memuat materi sistem reproduksi sudah valid. Saran diberikan validator berupa menambahkan materi perhitungan masa subur pada siklus mentruasi, membuat glosarium pada bagian akhir, dan membuat tampilan cover lebih menarik. Perbaikan modul didasarkan pada saran validator. Setelah Uji coba pada mahasiswa dilakukan setelah validasi untuk mengetahui kepraktisan modul. Modul sangat praktis ditunjukkan dari hasil uji coba juga dan dapat digunakan untuk proses pembelajaran materi sistem reproduksi matakuliah fisiologi hewan.

\section{SIMPULAN}

Modul berbasis inkuiri terbimbing berdasarkan hasil penelitian pada materi sistem reproduksi dihasilkan sudah sangat valid dan sangat praktis. Nilai validasi materi 94,84\%, media 92,43\%, dan praktisi lapangan 95,7\%. Nilai kepraktisan oleh mahasiswa 91,3\%. Modul berbasis inkuiri terbimbing berdasarkan hasil penelitian pada materi sistem reproduksi dihasilkan perlu dilakukan implementasi untuk mengetahui keefektifan modul dalam proses pembelajaran matakuliah fisiologi hewan. 


\section{DAFTAR RUJUKAN}

Aisyah, N., \& Purwoko. (2011). Meningkatan Hasil Belajar Mahasiswa menggunakan Modul. Jurnal Ilmu Pendidikan, 17(5), $393-400$.

Akbar, S. (2013). Instrumen Perangkat Pembelajaran. Bandung: PT Remaja Rosdakarya.

Amin, M. (2010). Hasil-hasil Penelitian Bidang Biologi dalam Pembelajaran (pp. 12-18). Seminar Nasional Pendidikan Biologi FKIP UNS.

Andika, I. M., Suadnyana, I. N., \& Zulaikha, S. (2014). Pengaruh Model Pembelajaran Inkuiri melalui Diskusi Kelompok Kecil terhadap Hasil Belajar Sains Siswa Kelas V SD Gugus 6 Batubulan. Mimbar PGSD Undhiksa, 2(1), 1-12.

Arifin, Z. (2009). Evaluasi Pembelajaran. Bandung: PT Remaja Rosdakarya.

Asyhar, R. (2011). Kreatif Mengembangkan Media Pembelajaran. Jakarta: Gaung Perasada Press.

Belawati, J. (2003). Pengembangan Bahan Ajar Edisi Kesatu. Jakarta: Pusat Penelitian Universitas Terbuka.

Branch, R. M. (2009). Instructional Design: The ADDIE Approach. London: Springer New York Dordecht Heidelberg.

Chiin, \& Malhotra. (2002). Epistemologically Authentic Inquiry in Schools: A Theoretical Framework for Evaluating Inquiry Tasks. Science Education, 175-218.

Darini, N. M., Martha, N., \& Artawan, G. (2013). Analisis Kualitas Tes Sumatif Bahasa Indonesia Kelas VIII SMPN 8 Denpasar Semester Genap Tahun 2012. Jurnal Pendidikan dan Pembelajaran Bahasa Indonesia, 2(19).

Daryanto. (2013). Menyusun Modul Bahan Ajar untuk Persiapan Guru Dalam Mengajar. Yogyakarta: Gava Media.

Faot, M. M., Zubaidah, S., \& Kuswantoro, H. (2016). Pengembangan Modul Teknik Budidaya Tanaman Kedelai sebagai Bahan Ajar Sekolah Menengah Kejuruan. Jurnal Pendidikan: Teori, Penelitian, dan Pendidikan, 1(7), 1421-1426.

Fitriani, E. (2017). Pengaruh Model Inquiry Learning Berbasis Assesment Kinerja terhadap Keterampilan Proses Sains pada Materi Sistem Peredaran Darah Peserta Didik Kelas XI di SMA N 8 Bandar Lampung. Skripsi tidak diterbitkan. Institut Islam Negeri Raden Intan, Lampung.

Fitro, S. E. (2014). Pengembangan Multemedia Interaktif Teknologi Hibridoma untuk Matakuliah Bioteknologi di Universitas Negeri Malang. Tesis tidak diterbitkan. Universitas Negeri Malang, Malang.

Heri, E. A. (2014). Pengembangan Modul Latihan Keterampilan Proses Sains untuk SMA/MA kelas X pada Materi Kinematika Gerak. Tesis tidak diterbitkan. Universitas Sebelas Maret, Surakarta.

Hidayat, S., Festiyed, \& Fauzi, A. (2012). Pengaruh Pemberian Assessment Essay terhadap Pencapaian Kompetensi Siswa Dalam Pembelajaran Fisika Menggunakan Pendekatan Ekspositori dan Inkuiri di Kelas XI IA SMA N 1 Kecamatan Suliki Kabupaten Lima Puluh Kota. Jurnal Penelitian Pembelajaran Fisika, 1(1), 1-14.

Karnes, F. A., \& Bean, S. M. (2009). Methods and Materials for Teaching the Gifted (third). United States of America: Prufrock Press Inc.

Kerangka Kualifikasi Nasional Indonesia. (2015). Paradigma Capaian Pembelajaran. Direktorat Jendral Pembelajaran dan Kemahasiswaan Kementrian Riset, Teknologi, dan Pendidikan Tinggi Republik Indonesia.

Lestari. (2013). Pengembangan Bahan Ajar Berbasis Kompetensi. Padang: Akademia.

Llewellyn, D. J. (2013). Teaching High School Science through Inquiry and Argumentation. USA: Corwin.

Mahfudhillah, H. T., \& Al-Muhdhar, M. H. I., \& Sueb. (2017). Pengembangan Modul Kawasan Rumah Pangan Lestari (KRPL) Berbasis Proyek. Jurnal Pendidikan: Teori, Penelitian, dan Pengembangan, 2(3), 400-408.

Mbulu, J. (2001). Pengajaran Individual. Malang: Elang Mas.

Oktavia, I., Sumitro, S. B., \& Lestari, U. (2015). Pengembangan Bahan Ajar Berbasis Penelitian Karakteristik Protein Membran Sperma pada Matakuliah Bioteknologi. Florea, 2(2), 33-42.

Parmin, \& Peniati, E. (2012). Pengembangan Modul Matakuliah Strategi Belajar Mengajar IPA Berbasis Hasil Penelitian Pembelajaran. Unnes Journal of Biology Education, 1(1), 8-15.

Peffer, M. E., Beckler, M. L., Schunn, C., Renken, M., \& Revak, A. (2015). Science Classroom Inquiry (SCI) Simulations: A Novel Method to Scaffold Science Learning. https://doi.org/10.1371/journal.pone.0120638

Permadi, B. A. (2016). Pengembangan Modul IPA Berbasis Integrasi Islam dan Sains untuk Meningkatkan Hasil Belajar Pada Siswa Kelas VI MIN Seduri Mojokerto. Universitas Islam Negeri Maulana Malik Ibrahim.

Pratama, D. R., Widiyatmoko, A., \& Wusqo, I. U. (2016). Pengaruh Penggunaan Modul Kontekstual Berpendekatan SETS terhadap Hasil Belajar dan Kemandirian Peserta Didik Kelas VII SMP. Unnes Science Education Journal, 5(3), 13661378.

Rizqiana, F. A., Widodo, A. T., \& Supardi, K. I. (2017). Pengembangan Bahan Ajar Kimia Berbasis Pendekatan Investigasi untuk Meningkatkan Kompetensi Siswa pada Materi Koloid. Journal of Innovative Science Education, 6(1), 75-94.

Sari, T. D., \& Isnur, S. H. (2015). Pengembangan Modul Pembelajaran Berbasis Proyek pada Mata Pelajaran Instalasi Penerangan Listrik untuk Mengetahui Peningkatan Hasil Belajar Siswa Kelas XI TIPTIL SMK Negeri 7 Surabaya. Jurnal Pendidikan Teknik Elektro, 4(2), 621-627.

Seeley, R. R., Stephens, T. D., \& Tate, P. (2008). Anayomy \& Fisiology: Eighth Edition. New York: The McGraw-Hill Companies.

Siddiq, M. D. (2008). Pengembangan Bahan Ajar. Depdiknas: Direktorat Jendral Pendidikan Tinggi.

Siswanto. (2006). Penggunaan Tes Essay Dalam Evaluasi Pembelajaran. Jurnal Pendidikan Akuntansi Indonesia, 5(1), 55-61. 
Sudjana, N., \& Rivai., A. (2009). Teknologi Pengajaran. Bandung: Sinar Baru Algensindo.

Susanti, E. (2016). Glosarium Kosakata Bahasa Indonesia dalam Ragam Media Sosial. Dialektika, 3(2), 229-250.

Susongko, P. (2010). Perbandingan Keefektifan Bentuk Tes Uraian dan Teslet dengan Penerapan Graded Response Model (GRM). Jurnal Penelitian dan Evaluasi Pendidikan, 14(3), 269-288.

Yahya, I. (2010). Manajemen Empat Langkah dalam Pengembangan Bahan Ajar Berbasis Riset: Sebuah Pengalaman dari Perkuliahan Akustik. Disajikan pada Pelatihan Penulisan Buku Ajar Berbasis Riset. In Semarang (Ed.). LPPM UNS. Yaomi, M. (2013). Prinsip-prinsip Desain Pembelajaran. Jakarta: PT Kencana.

Yuanda, R. Y., \& Ristiono, F. M. (2017). Pengembangan Modul Biologi Berbasis Metakognisi tentang Materi Sistem Koordinasi yang Dilengkapi Peta Konsep untuk Peserta Didik Kelas XI SMA/MA. Bioeducation Jurnal, 1(1), $74-87$.

Zulfadli. (2017). Pengembangan Modul Biologi pada Materi Ekosistem Berbasis Problem Based Learning untuk Siswa Kelas X SMA Muhammadiyah Kota Tarakan. Jurnal Bionature, 17(1), 63-67. 